\title{
Climate change: a top priority for public health
}

\section{Les changements climatiques : une priorité absolue pour la santé publique}

\author{
Louise Potvin $^{1} \cdot$ Jeff Masuda ${ }^{2}$ \\ Published online: 6 November 2020 \\ (C) The Canadian Public Health Association 2020
}

It was only about one year ago, although it seems like an eternity, that climate activist Greta Thunberg accused world leaders assembled at the 2019 UN Climate Action Summit in New York of stealing her dreams and childhood as well as those of an entire generation. In an emotional call for action, she reminded the world that two centuries of overexploitation of natural resources and half a century of inaction with respect to their increasingly global deleterious consequences have led the planet and those who inhabit it to an inevitable dead end. Despite the clear science behind the ecological and human impacts of climate change, she famously lamented, "How dare you continue to look away, and come here saying that you're doing enough when the politics and solutions are still nowhere in sight." Her accusation was as damning as it was laser-like in its target; the solutions to such a radical threat had to come from transformative political change - informed by sciencemore than from the sum of so many individual commitments to change our behaviours. She was arguing to the blind and obstinate adults in the room that the children were already willing to act.

One year, a global pandemic, and over 1.1 million deaths later (approximately the population of the city of Calgary), the target of staying below a 1.5 degree global temperature rise now seems further away than ever. Understandably, the energies of political leaders, scientific institutions, and economic

Louise Potvin

louise.potvin@umontreal.ca

1 School of Public Health, Université de Montréal, Montréal, QC, Canada

2 Canada Research Chair in Environmental Health Equity, School of Kinesiology and Health Studies, Queen's University, Kingston, ON, Canada global actors have focused on COVID-19, on strategies to control its spread or limit its health impact, and on ways to restart stalled national economies while mitigating the social disruptions of this major global disaster. Rightfully, our best minds are at work on solving this immediate threat and its consequences. But it would take an act of extreme cognitive dissonance to view the COVID-19 crisis as totally independent of the looming climate crisis, as well as the broader crisis of decades of economic globalization and ecological change, that surround it.

We should also not forget that in the world after COVID, or more likely, the world with SARS-CoV-2, the ineluctable impacts of climate change will not have suddenly disappeared from view. There is no historical precedent for the level of urgency to act: as shown through the rapid evolution of global warming and the unforeseen scope of its consequences, any action that science deems effective today will be obsolete 10 or even 5 years from now. One major message from science over the past 50 years of inaction is that the more we wait to make the necessary changes to our economy and consumption habits, the more severe the consequences and the more drastic the changes will have to be in the time of immediate threats, or in their aftermath. The lessons from the past six months of dealing with a major pandemic should be clear. When a major disrupter hits strongly and widely, the medicine to control its spread and limit its damage, at least in the short term, causes as much harm as the situation it addresses. What should be of deep concern to public health is how such disrupters have proven to be accelerators of inequalities and eventually of much broader social disorder that will be difficult to reverse.

Fortunately, voices are starting to be heard that raise awareness of a more hopeful future. We are beginning to see through the clouds of COVID how reinvestments in our social safety net can be an effective strategy to restart our economy. 
Societies are also now rehearsing en masse, whether willingly or not, a return to more sustainable, locally based lifestyles as a way to not only mitigate outbreaks but also reduce our global ecological footprint. We are learning to listen better to Indigenous knowledge holders, and to children, who hold the wisdom to teach us about the importance of intergenerational equity. These shifts are beginning to reset our political thinking at a fundamental level, helping us to break out of a century-long slumber that sees an economy based on fossil fuels, infinite consumption, individualism, and the acceptance of growing inequalities as the only viable way to organize our world. From the view of public health, we are convinced that over and above coming up with strategies to mitigate the impact of climate change on health, we have a critical role to play in designing and implementing lasting solutions that can help to inform and improve such transformative changes at a whole-of-society level. After all, we have been in the business of educating people, empowering community action, and effecting policy change for more than 150 years!

In this spirit of renewed leadership and political will, CJPH takes the opportunity given by the publication of a special section following our call for submissions "Moving on IPCC $1.5^{\circ} \mathrm{C}$ " to call upon the public health community-researchers, practitioners, and decision makers - to consider the relevance and impacts of their research, practice, and decisions, in terms of climate change and related global anthropogenic ecological shifts from pollution and ecotoxicity, resource depletion, and loss of biodiversity. Given the urgency of the situation, we are making Moving on IPCC $1.5^{\circ} \mathrm{C}$ a permanent call for submissions. We commit to treat submissions in answer to this call as priority and to ensure swift and rigorous peer review by a team of highly qualified reviewers. In the meanwhile, we hope that the papers and the invited commentary that are published in the special section of the current issue will convince more researchers to submit their work on climate change, climate change adaptations, and their implications for health equity to the Canadian Journal of Public Health for consideration.

Louise Potvin, $\mathrm{PhD}$

Editor-in-Chief, CJPH

Jeffrey Masuda, $\mathrm{PhD}$

Senior Editor, CJPH

\section{Éditorial}

C'était il y a environ un an, même si cela semble une éternité, que la militante pour le climat Greta Thunberg accusait les dirigeants mondiaux réunis au Sommet sur le climat de l'ONU à New York, en 2019, d'avoir volé ses rêves et son enfance et ceux de toute une génération. Dans un vibrant appel à l'action, elle rappelait au monde que deux siècles de surexploitation des ressources naturelles et un demi-siècle d'inaction face aux conséquences de plus en plus délétères de cette surexploitation ont mis la planète et ses habitants sur une voie sans issue. Malgré des données scientifiques claires des répercussions écologiques et humaines des changements climatiques, s'est-elle fameusement indignée, " Comment osez-vous encore regarder ailleurs? Vous venez ici pour dire que vous faites assez, alors que les politiques et les actions nécessaires sont inexistantes. » Son accusation était aussi accablante que ciblée avec une précision chirurgicale; les solutions à une menace aussi radicale doivent venir d'un changement politique radical—éclairé par la science — plus que de la somme de si nombreux engagements individuels à changer nos comportements. Elle faisait valoir à son auditoire d'adultes aveugles et obstinés que les enfants étaient déjà prêts à agir.

Un an, une pandémie mondiale et plus de 1,1 million de morts plus tard (environ la population de la ville de Calgary), l'objectif de limiter la hausse de la température planétaire à moins de 1,5 degré semble plus lointain que jamais. Naturellement, les dirigeants politiques, les institutions scientifiques et les acteurs de l'économie mondiale ont concentré leur énergie sur la COVID-19, sur les stratégies pour en contrôler la propagation ou en limiter les effets sanitaires, et sur les moyens de réactiver les économies nationales au point mort, tout en atténuant les perturbations sociales de cette grande catastrophe mondiale. À juste titre, nos meilleurs cerveaux s'emploient à lever la menace immédiate et ses conséquences. Mais cela prendrait un acte de dissonance cognitive extrême pour considérer la crise de la COVID-19 comme étant entièrement indépendante de la crise climatique qui plane, ainsi que de la crise plus large qui l'entoure, causée par des décennies de mondialisation de l'économie et de changements écologiques planétaires.

Il ne faudrait pas oublier que dans le monde de l'aprèsCOVID, ou plus probablement dans un monde avec le SRAS-Cov-2, l'impact inéluctable des changements climatiques n'aura pas soudainement disparu. L'histoire n'offre aucun précédent d'une telle urgence d'agir : comme nous le voyons à l'évolution rapide du réchauffement planétaire et à l'envergure imprévue de ses conséquences, toute intervention que la science juge efficace aujourd'hui sera caduque dans 10 ou même dans 5 ans. L'un des grands messages de la science au cours des 50 dernières années d'inaction est que plus nous attendons pour apporter les changements nécessaires à notre économie et à nos habitudes de consommation, plus graves seront les conséquences et plus radicaux les changements que nous devrons apporter quand la menace sera immédiate ou que nous devrons en atténuer les répercussions. Les leçons des six derniers mois de notre gestion d'une pandémie majeure devraient être claires. Quand une grave perturbation frappe avec force et à grande 
échelle, le remède pour en contrôler la propagation et en limiter les dommages, au moins à court terme, cause autant de torts que la situation à corriger. Ce qui devrait profondément inquiéter la santé publique, c'est que de telles perturbations se révèlent être des accélérateurs d'inégalités et, à terme, de troubles sociaux beaucoup plus vastes, qui seront difficiles à renverser.

Heureusement, des voix commencent à se faire entendre qui nous font prendre conscience d'un avenir plus ouvert. Nous commençons à voir, à travers les nuages de la COVID, que les réinvestissements dans notre filet de sécurité sociale peuvent être un moyen efficace de faire redémarrer notre économie. Volontairement ou non, les sociétés font actuellement l'apprentissage massif d'un retour à des modes de vie plus durables et locaux pour non seulement atténuer la contagion, mais réduire notre empreinte écologique mondiale. Nous apprenons à mieux écouter les détenteurs de savoirs autochtones, et les enfants, qui ont la sagesse de nous enseigner l'importance de l'équité intergénérationnelle. Ces changements commencent à remettre nos idées politiques en place à un niveau fondamental, et nous aident à nous réveiller d'un siècle de sommeil pendant lequel l'économie fondée sur les énergies fossiles, la consommation infinie, l'individualisme et l'acceptation des inégalités croissantes ont été perçus comme étant les seules façons viables d'organiser notre monde. Du point de vue de la santé publique, nous sommes convaincus qu'en plus de trouver des stratégies pour atténuer les répercussions des changements climatiques sur la santé, nous avons un rôle essentiel à jouer dans la conception et l'application de solutions durables, capables d'éclairer et d'améliorer des changements sociétaux aussi radicaux. Après tout, la sensibilisation de l'opinion publique, l'habilitation de l'action communautaire et le plaidoyer pour des politiques publiques favorisant la santé sont notre spécialité depuis plus de 150 ans!

Dans cet esprit de leadership et de volonté politique renouvelés, la RCSP profite de la publication d'une rubrique spéciale, à la suite d'un appel d'articles sur la «Réaction au cri d'alarme du GIEC », pour inviter la communauté de la santé publique - chercheurs, praticiens et décideurs - à examiner la pertinence et les effets de leurs recherches, de leurs pratiques et de leurs décisions sur les changements climatiques et les changements écologiques mondiaux connexes d'origine humaine liés à la pollution et à l'écotoxicité, à l'épuisement des ressources et à la perte de biodiversité. Étant donné l'urgence de la situation, nous faisons de la Réaction au cri d'alarme du GIEC un appel d'articles permanent. Nous nous engageons à traiter en priorité les envois en réponse à cet appel et à les faire évaluer rapidement et rigoureusement par une équipe de pairs hautement qualifiés. Entre-temps, nous espérons que les articles et le commentaire invité qui paraissent dans la rubrique spéciale du présent numéro convaincront d'autres chercheurs de soumettre à la Revue canadienne de santé publique leurs travaux sur les changements climatiques, les adaptations aux changements climatiques et leurs conséquences pour l'équité en santé.

Louise Potvin, Ph.D.

Rédactrice en chef, RCSP

Jeff Masuda, Ph.D.

Rédacteur scientifique adjoint, RCSP

Publisher's note Springer Nature remains neutral with regard to jurisdictional claims in published maps and institutional affiliations. 